\title{
Heat transfer between gas and the surrounding walls in the model of gas flow from the combustion chamber to the crankcase
}

\begin{abstract}
The paper discusses different approaches to the modeling of the heat transfer between gas and surrounding walls used in the models of gas flow from the combustion chamber to the crankcase. Most models described in the literature assume that the flow is isothermal or quasi-isothermal. Such an assumption remarkably simplifies the calculations, however, the real gas flow has an mixed character (between adiabatic and isothermal). Taking the above into account, the submodel of heat transfer, which allows assuming the conditions of heat transfer from isothermal to adiabatic was worked out and included into the model of the gas flow and ring dynamics. The research of the effect of the assumed heat transfer intensity on the calculated inter-ring gas pressures, rings axial positions in the grooves and blow-by has been presented in this paper.
\end{abstract}

Key words: combustion engine, blow-by, mathematical model, heat transfer

\section{Wymiana ciepła pomiędzy przepływającym gazem a ściankami w modelowaniu szczelności układu tłok-pierścienie-cylinder}

\begin{abstract}
W pracy dokonano przegląu sposobów modelowania wymiany ciepła pomiędzy gazem a otaczajacymi go ściankami wykorzystywanych w modelach przepływu gazu przez uszczelnienie tłok-pierścienie-cylinder (TPC). W większości opisanych w literaturze modeli założono, że przeptyw ten jest izotermiczny lub quasi-izotermiczny (takie założenie znaczaco upraszcza obliczenia). Przepływ rzeczywisty jest jednak przeplywem pośrednim pomiędzy izotermicznym a adiabatycznym. $W$ artykule opisano sposób modelowania wymiany ciepła zastosowany we własnym modelu uszczelnienia TPC. Sposób ten pozwala zakładać warunki wymiany ciepła od przepływu izotermicznego po adiabatyczny. Wykorzystujac powyższy model przeprowadzono symulacyjne badania wpływu intensywności wymiany ciepła na obliczane natężenie przedmuchów spalin i inne obliczane w modelu wielkości.
\end{abstract}

Słowa kluczowe: silnik spalinowy, przedmuchy spalin, model matematyczny, wymiana ciepła

\section{Introduction}

In modeling of the gas flow through the piston-ringscylinder seal it is commonly assumed, that the gas flows through a series of stages connected with throttling passages (labyrinth seal). Particular models differ from each other with the number of considered factors influencing the gas flow intensity. In the simplest models it is assumed that gas flows through only one stage of constant volume, corresponding to the top inter-ring space, and through two throttling passages of constant intersections, corresponding to the top and the end-gaps of the second compression ring [7]. In more advanced models a gas flow through crevices between side surfaces of the rings and the grooves is also considered, so the model consists of more stages and throttling passages. More factors influencing the volumes of the stages and cross-sections of the passages are also taken into account, e.g. ring axial and angular positions, cylinder, piston and rings thermal deformations $[1,4,6,8]$.

Regardless of the structural complexity of the labyrinth through which the gas flows from the combustion chamber to the crankcase, there are different approaches to modeling of the heat transfer between the gas and the surrounding walls.

In most of the cases described in the literature, it is assumed that the gas flow through the stages of the labyrinth

\section{Wprowadzenie}

Modelując przepływ gazu przez uszczelnienie TPC powszechnie przyjmuje się, że gaz przepływa przez wiele stopni połączonych ze sobą szczelinami dławiącymi (uszczelnienie labiryntowe). Poszczególne modele różnią się ilością uwzględnianych czynników wpływających na natężenie przepływu gazu. W najprostszych modelach zakłada się, że gaz przepływa przez jeden stopień o stałej objętości, odpowiadający przestrzeni międzypierścieniowej, i dwie szczeliny dławiące o stałych przekrojach, odpowiadające szczelinom w zamkach pierścieni [7]. W bardziej zaawansowanych modelach uwzględnia się również przepływy gazu szczelinami pomiędzy pierścieniem i rowkiem pierścieniowym tłoka, a więc model składa się z większej liczby szczelin dławiących, a niekiedy również stopni. Ponadto uwzględniany może być wpływ wielu innych czynników, takich jak przemieszczenia i skręcenia pierścieni, odkształcenia cieplne elementów itd. na objętości stopni i przekroje szczelin $[1,4,6,8]$.

Niezależnie od stopnia złożoności struktury labiryntu, przez który może płynąć gaz z komory spalania do skrzyni korbowej, spotykane są różne podejścia do wymiany ciepła pomiędzy gazem a otaczającymi go ściankami.

W większości spotykanych w literaturze modeli zakłada się, że przepływ gazu w stopniach labiryntu jest izotermicz- 
is isothermal (gas temperature in the stage is constant and equals to the piston temperature) [7] or quasi-isothermal (instantaneous gas temperature equals to the average from the piston and cylinder temperatures at a given height) $[1,6]$.

The above assumptions significantly simplify the calculations, as it is possible to determine the parameters of the gas in a labyrinth stage using only an equation of state

$$
\frac{\mathrm{dp}}{\mathrm{dt}}=\frac{\mathrm{RT}}{\mathrm{V}} \frac{\mathrm{dm}}{\mathrm{dt}}
$$

taking into account the law of mass conservation

$$
\frac{\mathrm{dm}}{\mathrm{dt}}=\dot{\mathrm{m}}_{\mathrm{in}}-\dot{\mathrm{m}}_{\text {out }} .
$$

However, real gas flow through the stages of the seal has a mixed nature (between isothermal and adiabatic) and in some researchers' opinion [5], even closer to the adiabatic.

Theoretical assessment whether the real flow is closer to isothermal or adiabatic is difficult. Taking into account the complexity of the models of the ring pack, it is almost impossible to predict in advance the effect of the assumed heat transfer on the results of the calculations. The aim of this work was to evaluate the influence of the assumed heat transfer intensity between the gas and the surrounding walls on the blow by rate and other parameters calculated with the use of the model of the ring pack.

\section{Model and methodology}

An integrated model of the gas flow through crevices of the ring pack and of ring movements in the grooves was used in this research. A detailed description of the model has been presented in [2]. The model assumed that the gas flows through a seal consisting of several stages linked together by the throttling passages. The stages were created by the inter- and behind-the-ring spaces, which were considered independently. The throttling passages were created by end-gaps of the ring and crevices between the side surfaces of the rings and the grooves (Fig. 1). The model took into account thermal deformations of the cylinder kit components while determining instantaneous (as a function of crank angle) values of the stages volumes and ring end-gaps cross-sections. The cross-sections of the crevices between the side surfaces of the rings and the grooves resulted from instantaneous axial positions of the rings in the grooves. The axial positions of the rings in their grooves were calculated with the consideration of the forces of the gas pressure, ring friction against the cylinder and the inertia. The mass rates of the gas flow through the crevices were calculated assuming that the flow was isentropic through the orifice with the consideration for sub-critical and critical flows and taking into account the discharge coefficients.

Assuming the mixed flow (between isothermal and adiabatic) significantly complicated the model and forced to determine the heat transfer between the flowing gas and the surroundings and to determine the thermodynamic parameters of the gas in a given stage.

In the described model the thermodynamic parameters of the gas were determined from the law of energy conservation ny (temperatura gazu w stopniu jest stała i równa temperaturze tłoka w danym miejscu) [7] lub quasi-izotermiczny (chwilowa temperatura gazu równa jest średniej z temperatury tłoka i cylindra na wysokości, na jakiej w danej chwili znajduje się przestrzeń międzypierścieniowa) [1,6].

Założenia powyższe znacząco upraszczają obliczenia, gdyż pozwalają wyznaczyć parametry czynnika w danym stopniu labiryntu za pomocą tylko równania stanu gazu (1), uwzględniając zasadę zachowania masy (2).

Jednak rzeczywisty przepływ gazu przez stopnie uszczelnienia ma charakter pośredni między izotermicznym a adiabatycznym i zdaniem niektórych autorów [5] jest nawet bliższy adiabatycznemu.

Rozstrzygnięcie na drodze rozważań teoretycznych, czy rzeczywisty przepływ bliższy jest izotermicznemu czy adiabatycznemu jest trudne. Trudno jest również ocenić, bez wykonywania obliczeń symulacyjnych, jaki wpływ na natężenie przedmuchów spalin i inne parametry wyznaczane z wykorzystaniem modeli uszczelnienia TPC ma założona wymiana ciepła. W niniejszym artykule postanowiono ocenić wpływ zakładanej intensywności wymiany ciepła pomiędzy przepływającym przez uszczelnienie TPC gazem a otaczającymi go ściankami na wyniki obliczeń.

\section{Model i metoda badań}

W badaniach wykorzystano, opisany wcześniej [2], zintegrowany model przepływu gazu przez uszczelnienie tłok-pierścienie-cylinder i przemieszczeń pierścieni w rowkach pierścieniowych tłoka. W modelu tym założono, że gaz przepływa przez uszczelnienie składające się z wielu stopni połączonych ze sobą szczelinami dławiącymi. Stopnie te odpowiadają przestrzeniom międzypierścieniowym i zapierścieniowym - w modelu przestrzenie te potraktowano jako odrębne stopnie. Szczeliny dławiące odpowiadają zamkom pierścieni oraz szczelinom pomiędzy bocznymi powierzchniami pierścieni i rowków (rys. 1). Przy wyznaczaniu chwilowych wartości (w funkcji kąta obrotu wału korbowego) objętości poszczególnych stopni i przekrojów szczelin w zamkach pierścieni uwzględniono odkształcenia cieplne elementów układu TPC. Przekroje szczelin pomiędzy bocznymi powierzchniami pierścieni i rowków wynikają z chwilowych położeń osiowych pierścieni w rowkach. Osiowe położenia pierścieni w rowkach wyznaczane są $\mathrm{z}$ uwzględnieniem działających na nie sił: ciśnienia gazów, tarcia pierścieni o cylinder i bezwładności. Masowe natężenia przepływu gazu wyznaczane są przy założeniu, że przepływ przez szczeliny jest izentropowym przepływem przez kryzę, przy czym rozpatrzono przypadki przepływu podkrytycznego i krytycznego oraz uwzględniono empiryczny współczynnik przepływu.

Przyjęcie przepływu pośredniego, pomiędzy adiabatycznym a izotermicznym, znacznie komplikuje model, gdyż zmusza do wyznaczenia wymiany ciepła pomiędzy gazem a otaczającymi go ściankami i uwzględnienia tej wymiany przy wyznaczaniu parametrów termodynamicznych czynnika w stopniu.

W wykorzystanym modelu parametry termofizyczne gazu w stopniu wyznaczane są z zasady zachowania energii 


$$
\dot{\mathrm{U}}=\mathrm{i}_{\text {in }} \dot{\mathrm{m}}_{\text {in }}-\mathrm{i}_{\text {out }} \dot{\mathrm{m}}_{\text {out }}+\dot{\mathrm{Q}}-\mathrm{p} \dot{\mathrm{V}},
$$

where change of the gas internal energy resulted from the total enthalpy incoming and outgoing from the stage with the stream of the gas, heat transfer with the surroundings and work of volume change.

Considering the law of mass conservation (2) and excluding kinetic energy of the gas in the stage, and assuming that the flowing medium is a semi-ideal gas, temperature changes in the stage were calculated from the following equation

$$
\dot{\mathrm{T}}=\frac{1}{\mathrm{c}_{\mathrm{v}} \mathrm{m}}\left(\left(\mathrm{i}_{\mathrm{in}}-\mathrm{u}\right) \dot{\mathrm{m}}_{\mathrm{in}}-\mathrm{RT} \dot{\mathrm{m}}_{\text {out }}+\dot{\mathrm{Q}}-\mathrm{p} \dot{\mathrm{V}}\right)
$$

Gas pressures in the stages were calculated using state equation, and the flux of the transferred heat was calculated form Newton's law of cooling

$$
\mathrm{q}=\alpha\left(\mathrm{T}_{\text {wall }}-\mathrm{T}\right) .
$$

In particular, heat transfer rate between the surrounding walls and the gas in the crevice of the piston crown and in the inter-ring spaces (stages 1, 3, and 5 in Fig. 1) was calculated from the formula

$$
\dot{\mathrm{Q}}=\mathrm{S}_{\mathrm{c}} \alpha_{\mathrm{c}}\left(\mathrm{T}_{\mathrm{c}}-\mathrm{T}\right)+\mathrm{S}_{\mathrm{p}} \alpha_{\mathrm{p}}\left(\mathrm{T}_{\mathrm{p}}-\mathrm{T}\right)
$$

whereas for the behind-ring spaces (stages 2 and 4 in Fig. 1) it was calculated from the equation

$$
\dot{Q}=S_{p} \alpha_{p}\left(T_{p}-T\right)+S_{r} \alpha_{r}\left(T_{r}-T\right)
$$

In the calculations it is possible to use average values of heat transfer coefficients, which are available in the literature, or determine them using equations based on the theory of similarity $[2,5]$. In the presented research the first method was used, i.e. calculations were done using constant values of heat transfer coefficients.

The methodology of determining the thermodynamic parameters of the gas in the stages and heat transfer between the gas and the surrounding walls applied in the model permits modeling of the gas flow through the seal with various intensity of heat transfer, including special cases of adiabatic flow $(\mathrm{Q}=$ $=0$ ) and isothermal flow (heat transfer coefficient infinite).

The model was identified for the naturally aspirated diesel engine in a way which was described in [3]. The input data necessary for the calculations was obtained from the engine technical documentation and from the measurements of the components. As for the dimensions determining the volumes of stages and cross-sections of the throttling passages, thermal deformations were added to the cold-measured values. Temperatures and thermal deformations of components for the different conditions of the engine operation were calculated using Finite Element Methods. The indicated pressures for different engine operation conditions indispensable for the calculations came from the measurements made on the engine during the test stand research.
- wzór (3), gdzie zmiana energii wewnętrznej gazu związana jest $z$ entalpią całkowitą dopływającą i wypływającą ze stopnia wraz ze strumieniem gazu, wymianą ciepła z otoczeniem oraz pracą zmiany objętości.

Uwzględniając zasadę zachowania masy (2) i pomijając energię kinetyczną gazu w stopniu oraz zakładając, że przepływającym czynnikiem jest gaz półdoskonały, zmiany temperatury gazu w stopniu wyznaczane są z równania (4).

Ciśnienia gazu w stopniach wyznaczane są z równania stanu gazu, a gęstości strumienia przejmowanego ciepła wyznaczane są z prawa Newtona - wzór (5).

W szczególności w modelu strumienie ciepła wymienianego pomiędzy otaczającymi ściankami a gazem znajdującym się w szczelinie korony toka oraz $\mathrm{w}$ przestrzeniach międzypierścieniowych (stopnie 1, 3 i 5 na rys. 1) obliczane są ze wzoru (6), natomiast dla przestrzeni zapierścieniowych (stopnie 2 i 4 na rys. 1) obliczane są ze wzoru (7).
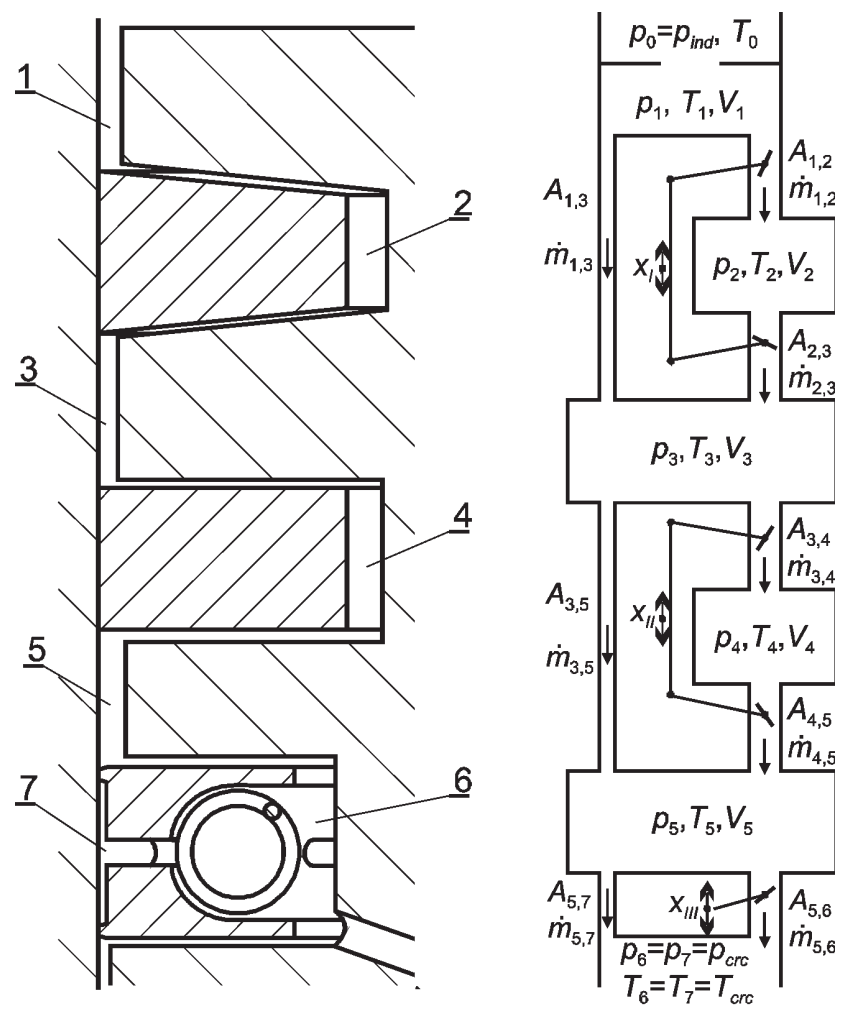

Fig. 1. Schematics of the ring pack and the corresponding model of labyrinth seal

Rys. 1. Schemat uszczelnienia pierścieniowego i odpowiadający mu model uszczelnienia labiryntowego

W obliczeniach można korzystać ze średnich wartości współczynników przejmowania ciepła podawanych w dość szerokich granicach w literaturze, lub wyznaczać te współczynniki, korzystając z wzorów opartych na teorii podobieństwa $[2,5]$. W prezentowanych badaniach wykorzystano pierwszy sposób, tzn. obliczenia przeprowadzono, podstawiając stałe wartości współczynników przejmowania ciepła.

Zastosowany w modelu sposób wyznaczania parametrów termodynamicznych gazu w stopniach i wymiany 


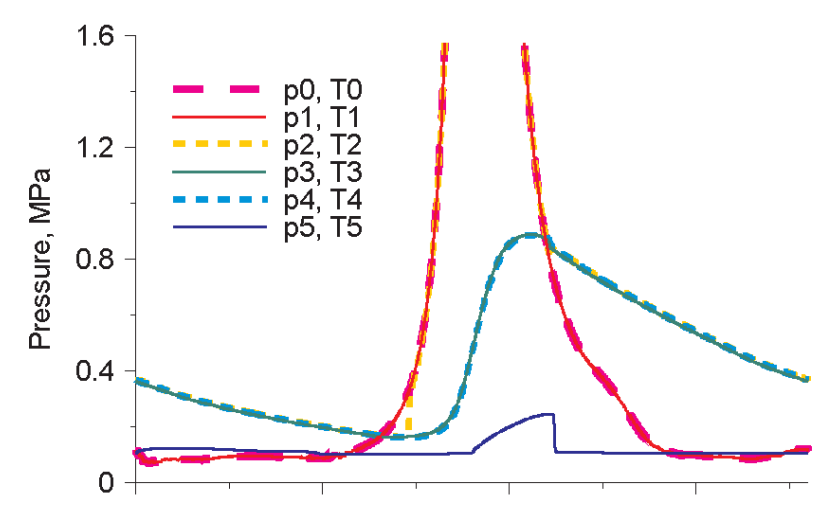

ciepła pomiędzy gazem a ściankami pozwalał modelować przepływ gazu przez uszczelnienie przy różnej intensywności wymiany ciepła między gazem a ściankami, w tym, jako przypadki szczególne, przepływy: adiabatyczny $(\mathrm{Q}=$ $=0$ ) oraz izotermiczny (współczynnik przejmowania ciepła nieskończenie duży).

Model zidentyfikowano dla wolnossącego silnika wysokoprężnego w sposób szczegółowo opisany wcześniej [3]. Niezbędne do przeprowadzenia obliczeń dane ustalono na podstawie dokumentacji technicznej silnika oraz bezpośrednich pomiarów elementów silnika. W przypadku wymiarów decydujących o objętościach stopni labiryntu

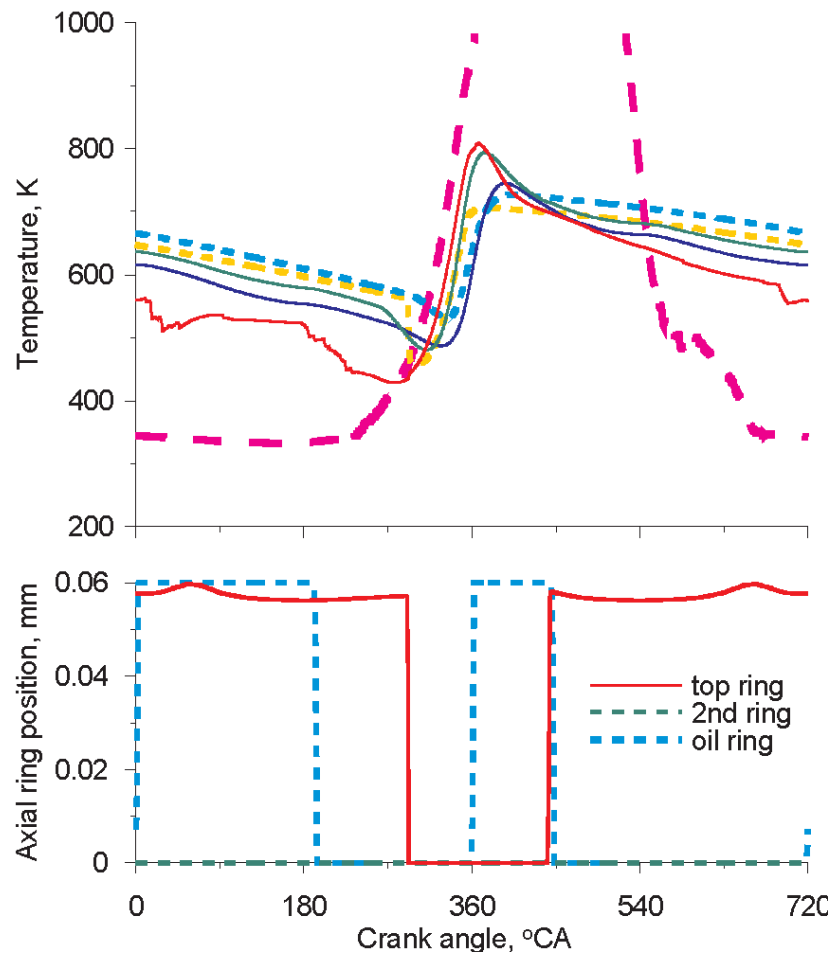

Fig. 2. Pressure and temperature courses in the inter-ring spaces and axial positions of the rings in the piston grooves determined for the engine full load at $2000 \mathrm{rpm}$

Rys. 2. Przebiegi ciśnień i temperatur gazu w przestrzeniach międzypierścieniowych oraz osiowe położenia pierścieni w rowkach tłoka wyznaczone za pomoca modelu dla petnego obciązenia silnika przy $2000 \mathrm{obr} / \mathrm{min}$

Simulations were done for two engine operating conditions: full load at 2000 and $4000 \mathrm{rpm}$. These engine speeds were selected because corresponding behaviors of the rings were very different, which, consequently, influenced the courses of pressure and temperatures of the gas in the inter-ring spaces. At $2000 \mathrm{rpm}$ the rings changed their axial position in their grooves only a few times, and the second compression ring was not changing its position at all - adhered to the bottom shelf of the groove during the whole engine cycle (Fig. 2). At 4000 rpm rings, particularly the second one, changed their position in the grooves repeatedly, what generated rapid changes of pressure in the corresponding inter-ring spaces (Fig. 3). Values of heat transfer coefficients used for these calculations were determined on oraz o przekrojach szczelin dławiących do zmierzonych na zimno wielkości dodano odkształcenia cieplne. Temperatury i odkształcenia cieplne elementów, w różnych warunkach
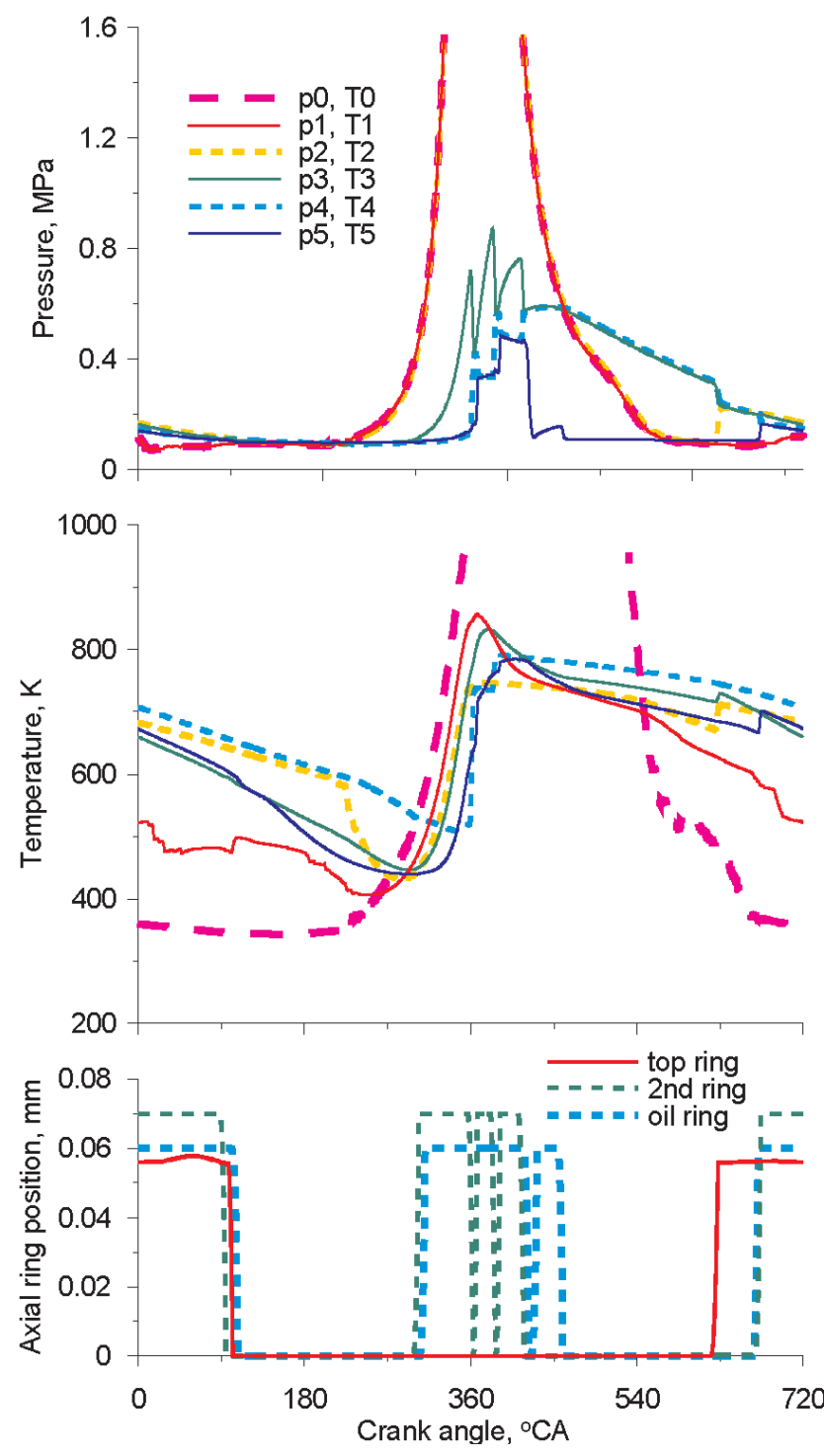

Fig. 3. Pressure and temperature courses in the inter-ring spaces and axial positions of the rings in the piston grooves determined for the engine full load at $4000 \mathrm{rpm}$

Rys. 3. Przebiegi ciśnień i temperatur gazu w przestrzeniach międzypierścieniowych oraz osiowe położenia pierścieni w rowkach tłoka wyznaczone za pomoca modelu dla petnego obciażenia silnika przy $4000 \mathrm{obr} / \mathrm{min}$ 
the basis of the literature analysis and preliminary calculations. These values in the later part of the paper are referred to as "normal".

The investigations of the influence of the heat transfer intensity on the results obtained in the model calculations were carried out using different values of the heat transfer coefficients, varied in broad range and keeping constant values of the remaining input data.

\section{Results of simulations}

Figures 4 to 9 show the courses of temperature and pressure of the gas in the inter-ring spaces and positions of rings in their grooves calculated for different values of the heat transfer coefficient: normal, 10-times bigger and 10-times smaller than normal, and for 0 and very high values. Heat transfer coefficients equal to 0 (zero) mean that there was no heat transfer and signify that the flow of the gas through the stages was adiabatic, whereas very high values of the heat transfer coefficients (practically infinitely high) means that the flow was quasi-isothermal.

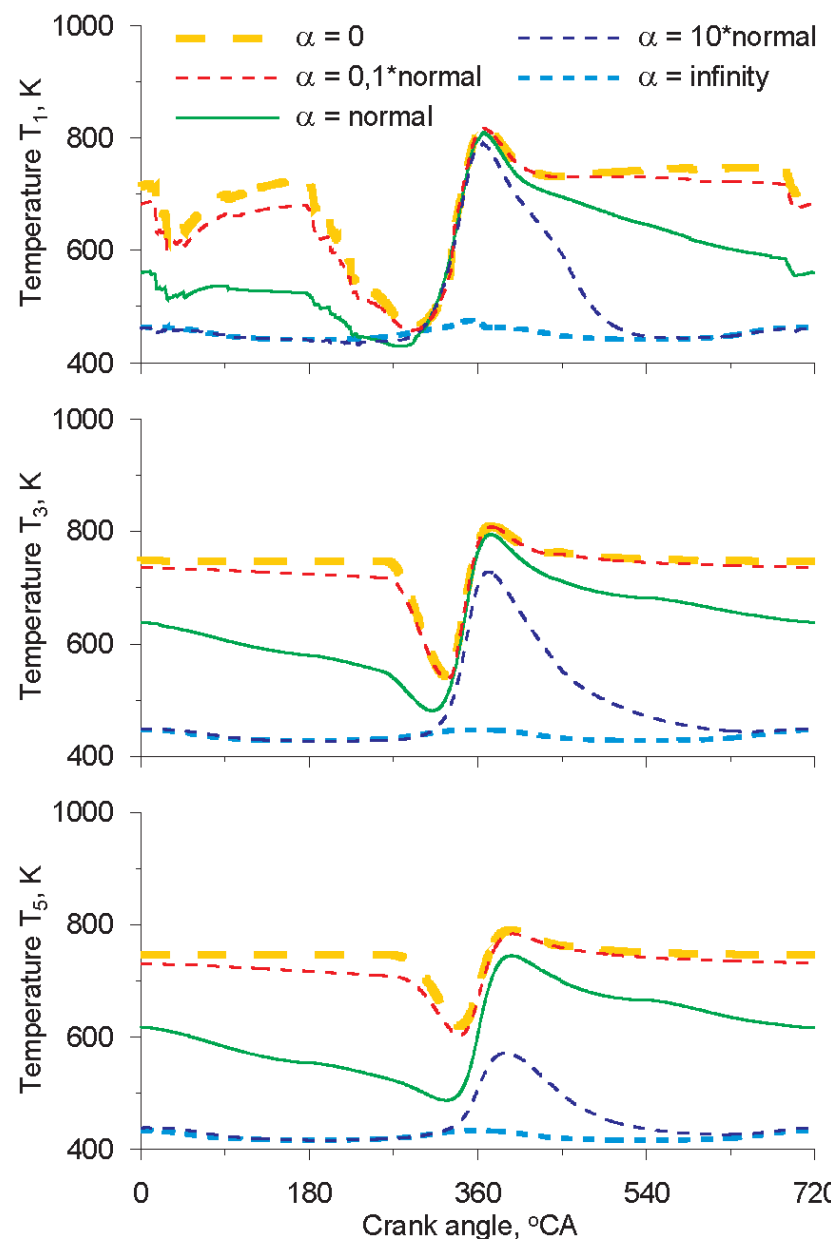

Fig. 4. Temperature courses in the piston crown crevice T1 and in interring spaces $\mathrm{T} 3$ and $\mathrm{T} 5$ calculated for the different values of heat transfer coefficient at full load of the engine at $2000 \mathrm{rpm}$

Rys. 4. Przebiegi temperatur w szczelinie korony tłoka T1 oraz $w$ przestrzeniach międzypierścieniowych T3 $i$ T5 obliczone przy różnych współczynnikach przejmowania ciepła dla petnego obciążenia silnika przy $2000 \mathrm{obr} / \mathrm{min}$ pracy silnika, wyznaczono z wykorzystaniem metody elementów skończonych. Niezbędne do przeprowadzenia obliczeń przebiegi ciśnień w komorze spalania pochodziły z pomiarów wykonanych na hamowni silnikowej.

Badania symulacyjne przeprowadzono dla dwóch punktów pracy silnika: pełne obciążenie przy 2000 i 4000 obr/min. Prędkości te wybrano, ponieważ znacząco różne były przy nich zachowania pierścieni, co w konsekwencji powodowało różne przebiegi ciśnień i temperatur gazu w przestrzeniach międzypierścieniowych. Przy 2000 obr/min pierścienie zmieniały swoje osiowe położenia w rowkach tylko kilka razy, a drugi pierścień uszczelniający nie zmieniał swojego położenia w ogóle - przylegał do dolnej półki rowka przez cały cykl pracy silnika (rys. 2). Natomiast przy 4000 obr/min pierścienie, w szczególności drugi, zmieniały swoje pozycje w rowkach wielokrotnie, co wywoływało gwałtowne zmiany ciśnień w sąsiadujących z nimi przestrzeniach międzypierścieniowych (rys. 3). Wartości współczynników wymiany ciepła, przy których przeprowadzono powyższe obliczenia ustalono na podstawie analizy literatury i obliczeń wstępnych. Wartości te w dalszej części artykułu i na wykresach nazywane są ,normalnymi”.

Badania wpływu intensywności wymiany ciepła na wyniki generowane przez model polegały na przeprowadzeniu obliczeń dla różnych wartości współczynników przejmowania ciepła, wariantowanych w bardzo szerokich granicach, przy niezmienionych pozostałych danych wejściowych.

\section{Wyniki obliczeń}

Na rysunkach 4-9 przedstawiono wyznaczone za pomocą modelu przebiegi temperatur i ciśnień gazu w przestrzeniach międzypierścieniowych oraz położeń osiowych pierścieni w rowkach przy następujących wartościach współczynników przejmowania ciepła: normalnych, 10 razy większych i 10 razy mniejszych od normalnych oraz równych 0 i bardzo dużych wartościach. Obliczenia przeprowadzone przy wartościach równych zero oznaczają brak wymiany ciepła, a więc adiabatyczny przepływ gazu przez stopnie labiryntu, natomiast wartości bardzo duże, praktycznie można je uznać za nieskończenie wielkie, oznaczają, że przepływ jest quasi-izotermiczny.

Intensywność wymiany ciepła pomiędzy gazem a otaczającymi go ściankami miała zasadniczy wpływ na wyznaczone temperatury gazu w poszczególnych przestrzeniach labiryntu (rys. 4 i 5). Średnie temperatury w obiegu były tym mniejsze, im większa była intensywność wymiany ciepła. Przy bardzo dużej wymianie ciepła temperatury gazu w stopniach równe były chwilowym średnim ważonym z temperatur otaczających ścianek. Należy podkreślić, że model przy obliczaniu temperatury był bardzo czuły na zmiany wartości współczynnika przejmowania ciepła w zakresie wartości podawanych w literaturze. Dwukrotne zwiększenie lub zmniejszenie współczynników w stosunku do przyjętej wartości normalnej powodowało znaczące różnice w przebiegach temperatur.

Intensywność wymiany ciepła różnie wpływała na kąt położenia wału korbowego, przy którym pierścienie zmieniały swoje osiowe położenia w rowkach (rys. 6 i 7). W 

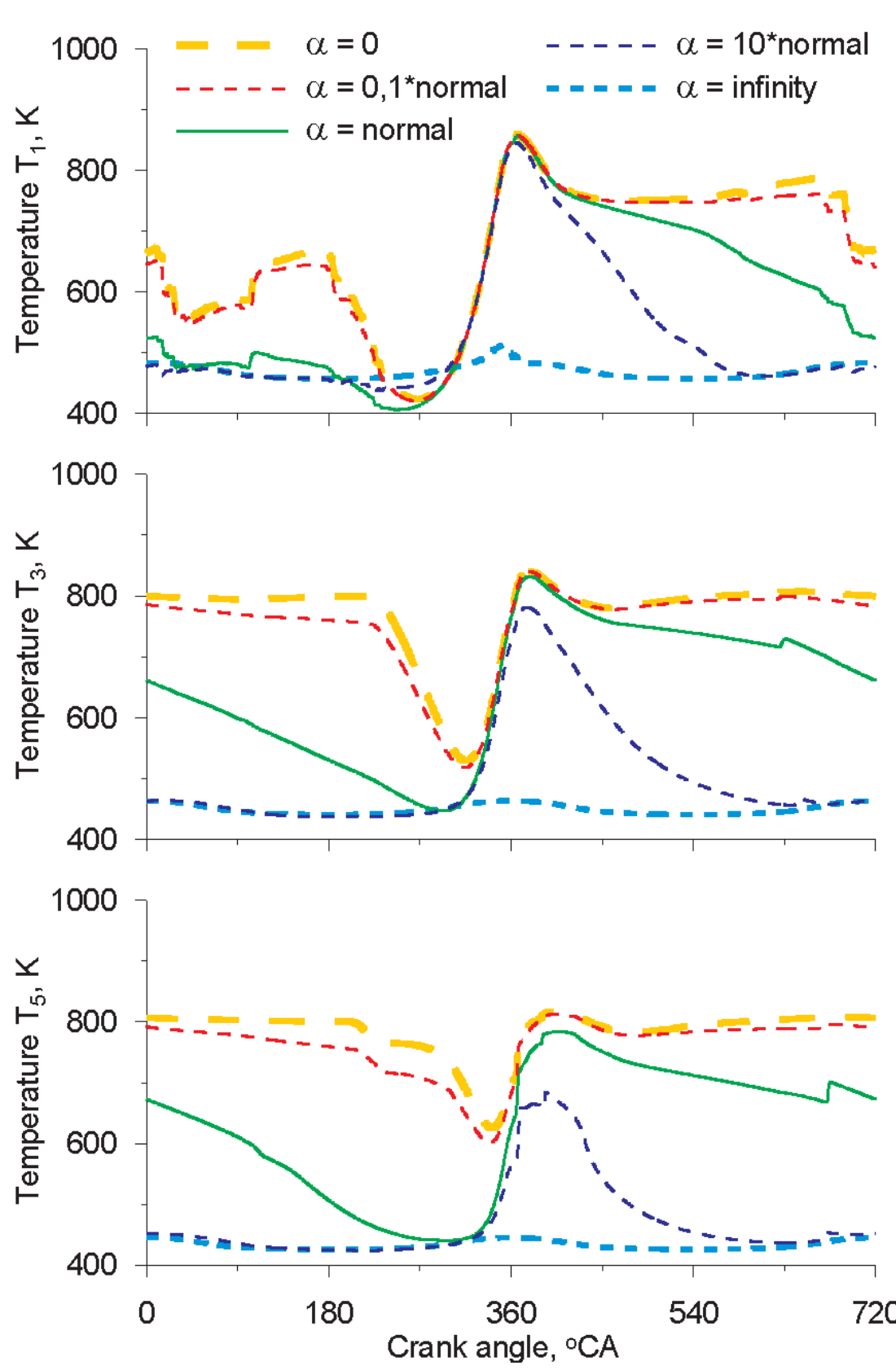

Fig. 5. Temperature courses in the piston crown crevice T1 and in interring spaces T3 and T5 calculated for the different values of the heat transfer coefficient at full load of the engine at $4000 \mathrm{rpm}$

Rys. 5. Przebiegi temperatur $w$ szczelinie korony tłoka 11 oraz $w$ przestrzeniach międzypierścieniowych T3 i T5 obliczone przy różnych współczynnikach przejmowania ciepła dla petnego obciązenia silnika przy $4000 \mathrm{obr} / \mathrm{min}$

The intensity of heat transfer between the gas and the surrounding walls had a significant influence on the determined gas temperatures in individual stages of the labyrinth (Fig. 4 and 5). It was observed, that the increasing intensity of the heat transfer was accompanied by lower mean temperatures of the gas within the cycle. At very high intensity of the heat transfer gas temperatures in individual stages were equal to instantaneous weighted average temperatures of the surrounding walls. It should be pointed out, that the model with regard to the calculations of the temperature was very sensitive to the changes of the heat transfer coefficient within the pewnych przypadkach nawet bardzo duża zmiana współczynnika przejmowania ciepła niemal nie wpływała na położenie kątowe wału, przy którym pierścień przemieszczał się w rowku, a innym razem powodowała, że pierścień przemieszczał się w rowku o kilkadziesiąt stopni wcześniej lub później w stosunku do przypadku „normalnego".

W większości analizowanych przypadków wartości współczynnika przewodzenia ciepła nie wpływały jednak na zachowania pierścieni w sensie jakościowym - kształty krzywych położenia danego pierścienia są podobne (rys. 6 i 7). Wyjątkiem było zachowanie pierścienia olejowego przy $4000 \mathrm{obr} / \mathrm{min}$. Pierścień ten w suwie pracy dla wartości $\alpha$ : normalnej, 10 razy mniejszej i równej zeru trzy razy zmieniał swoje położenie $\mathrm{w}$ rowku, podczas gdy dla wartości $\alpha$ : 10 razy większej od normalnej i równej nieskończoności przemieścił się w rowku tylko jeden raz (rys. 7).

Wyznaczone w modelu przebiegi ciśnień w przestrzeniach międzypierścienowych były do siebie zbliżone dla wartości $\alpha$ : normalnej, 10 razy mniejszej i równej 0 , natomiast dla wartości 10 razy większej i równej nieskończoności wartości ciśnień w suwie pracy były mniejsze (rys. 8 i 9). Widoczne na rys. 9 gwałtowne zmiany ciśnień związane są z przemieszczeniami pierścieni w rowkach.

Wpływ założonej intensywności wymiany ciepła pomiędzy gazem a otaczającymi go ściankami na obliczone wartości natężenia przedmuchów spalin do skrzyni korbowej przedstawiono na rys. 10. Zmiana wartości współczynników przejmowania ciepła w zakresie od 0 do 10 razy większych od normalnej miała bardzo mały wpływ na obliczone natężenie przedmuchów spalin. Natomiast przyjęcie bardzo dużych wartości tych współczynników powodowało, że obliczane przedmuchy były znacząco większe. Przy przepływie izotermicznym przedmuchy były o $20 \%$, przy prędkości $2000 \mathrm{obr} / \mathrm{min}$, i $35 \%$, przy $4000 \mathrm{obr} / \mathrm{min}$, większe niż przy przepływie obliczonym dla normalnych wartości współczynników przejmowania ciepła.

\section{Podsumowanie}

W pracy, wykorzystując przystosowany model uszczelnienia TPC, przeprowadzono symulacyjne badania wpływu intensywności wymiany ciepła pomiędzy przepływającym gazem a otaczającymi go ściankami na obliczane wartości: 

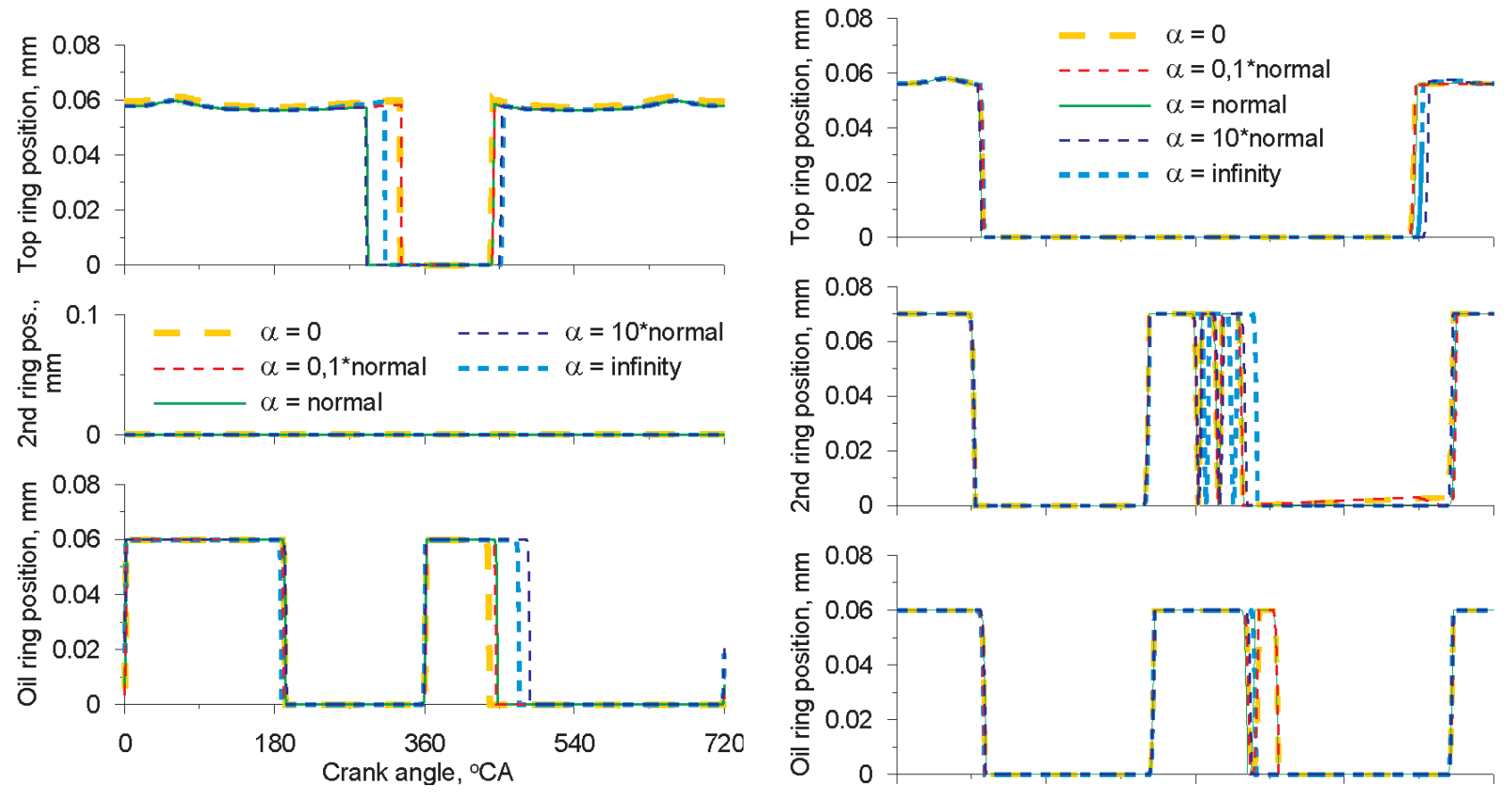

Fig. 6. Axial displacements of the rings in the piston grooves calculated for the different values of the heat transfer coefficient at full load of the engine at $2000 \mathrm{rpm}$

Rys. 6. Przemieszczenia osiowe pierścieni w rowkach tłoka obliczone przy różnych wspótczynnikach przejmowania ciepła dla petnego obciażenia silnika przy $2000 \mathrm{obr} / \mathrm{min}$

range of values given in the literature. Double increase or drop in the value of the coefficients in relation to the accepted normal value resulted in significant differences in the temperature courses.

The intensity of the heat transfer could influence the position of the crankshaft at which the rings changed their axial positions in the grooves (Figs. 6 and 7). Quantitatively this influence was different. In certain cases the change of the heat transfer coefficient caused that the rings changed their axial positions in the grooves tens of degrees earlier or later in comparison to the normal value of the coefficient. In other cases even very large change in the value of the heat transfer coefficient practically did not influence the crankshaft angle at which the rings moved in the grooves.

In most of the analyzed cases the values of the heat transfer coefficient still did not change the behavior of the rings in the qualitative meaning - the shapes of the curves representing the positions of the given ring were similar. The exception was the behavior of the oil ring at $4000 \mathrm{rpm}$. Oil ring 3 times changed its position in the groove in the power stroke for the coefficient values: normal, 10-times lower than normal and equal to 0 , whereas for the coefficient values: 10 -times higher than normal and equal to infinity moved in the groove only once (Fig. 7).

The determined pressure courses in the inter-ring spaces were similar to each other for the heat transfer coefficient values: normal, 10-times lower and equal to
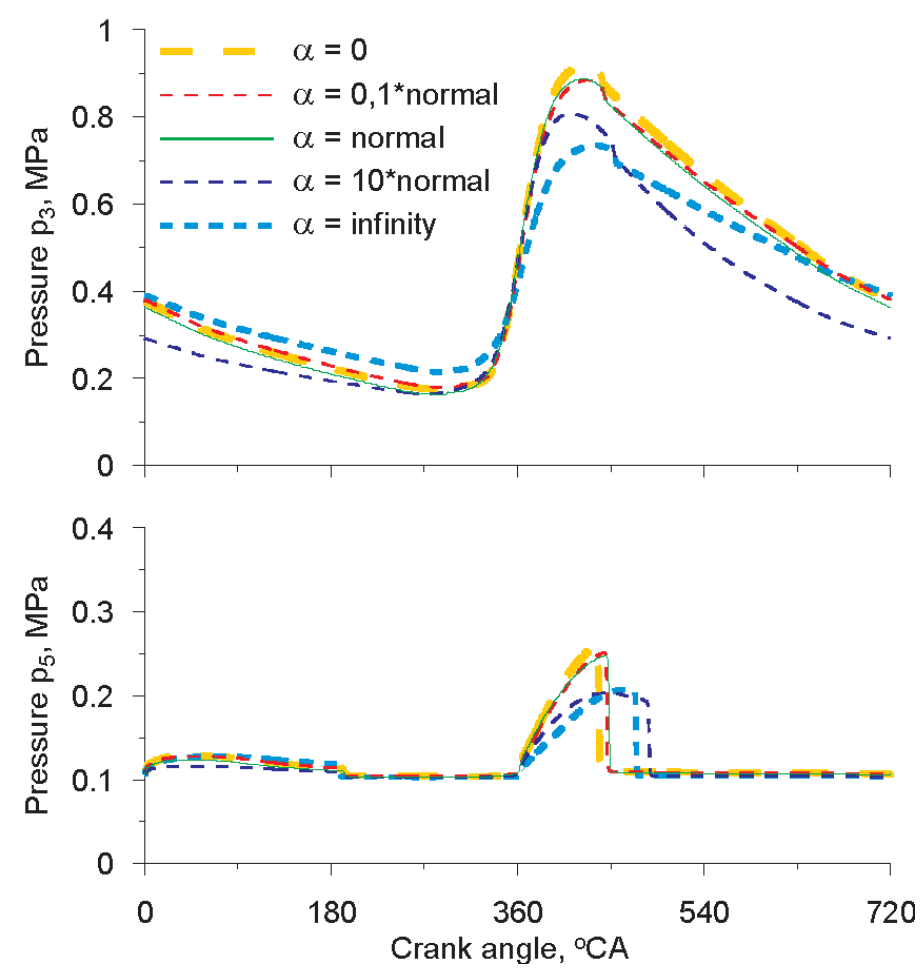

Fig. 8. Pressure courses in the inter-ring spaces calculated for the different values of the heat transfer coefficient at full load of the engine at $2000 \mathrm{rpm}$

Rys. 8. Przebiegi ciśnień w przestrzeniach międzypierścieniowych obliczone przy różnych wspótczynnikach przejmowania ciepła dla petnego obciązenia silnika przy $2000 \mathrm{obr} / \mathrm{min}$ 
0 , whereas for the values: 10 -times higher and infinity - the pressures in the power stroke were lower (Figs. 8 and 9). Rapid pressure changes were related to the displacement of rings in their grooves.

The influence of the assumed intensity of the heat transfer between the gas and the surrounding walls on the calculated blow by is shown in Fig. 10. the change of the value of the heat transfer coefficients in the range from 0 to 10 -times higher than the normal value had very low influence on the determined blow by. The assumption of higher values of this coefficient resulted in a significantly higher blow by. At an isothermal flow (the value of the coefficient equaled to infinity) the blow by was approx. $20 \%$ higher at 2000 rpm and $35 \%$ higher at $4000 \mathrm{rpm}$ than for the blow by calculated for normal values of heat transfer coefficients.

\section{Conclusions}

A numerical investigation of the effect of an assumed intensity of heat transfer between the gas flowing through a ring pack and the surrounding walls on the calculated values of temperature and pressure of the gas in the inter-ring spaces, axial displacements of rings in their grooves and blow by was carried out. A research was done using an adapted model of the gas flow from the combustion chamber to the crankcase integrated with the model of ring dynamics.

The assumed intensity of the heat transfer was essential for the calculated gas temperatures. Yet, from the point of view of practical applications, determining

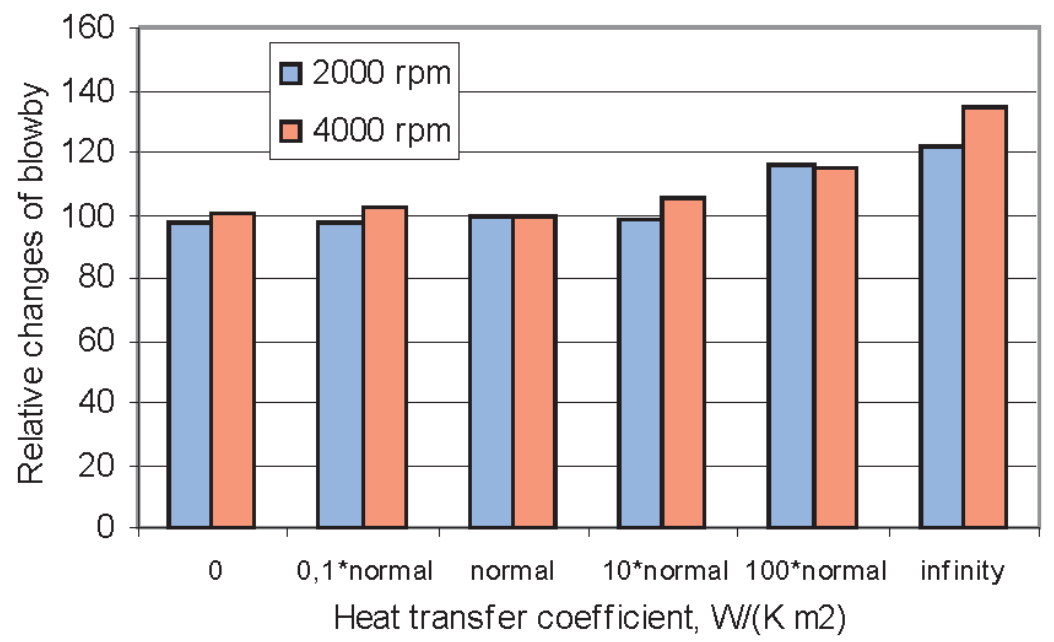

Fig. 10. The effect of heat transfer coefficient on the calculated values of the blow by rate

Rys. 10. Wpływ wspótczynnika przejmowania ciepła na obliczone wartości natężenia przedmuchów spalin do skrzyni korbowej
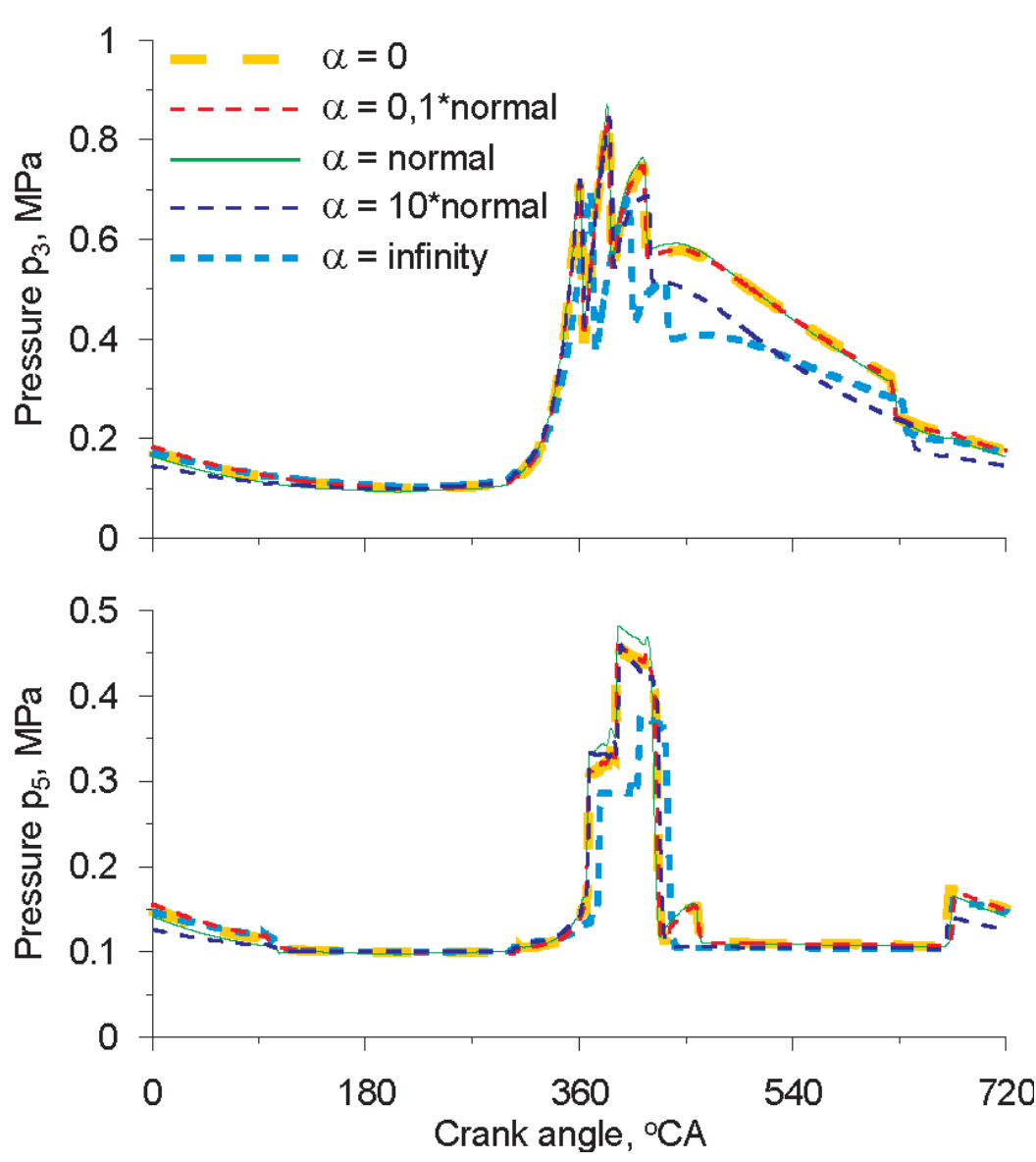

Fig. 9. Pressure courses in the inter-ring spaces calculated for the different values of the heat transfer coefficient at full load of the engine at $4000 \mathrm{rpm}$

Rys. 9. Przebiegi ciśnień w przestrzeniach międzypierścieniowych obliczone przy różnych wspótczynnikach przejmowania ciepła dla petnego obciążenia silnika przy $4000 \mathrm{obr} / \mathrm{min}$

temperatur i ciśnień gazu w przestrzeniach międzypierścieniowych, osiowe położenia pierścieni w rowkach oraz natężenie przedmuchów spalin do skrzyni korbowej.

Z wszystkich wyżej wymienionych obliczanych wielkości najbardziej wrażliwa na przyjętą intensywność wymiany ciepła jest temperatura gazu. Jednak celem prowadzenia obliczeń z wykorzystaniem takich modeli nie jest wyznaczenie temperatury gazu. Istotne są pozostałe wielkości, gdyż: wyznaczone ciśnienia wykorzystywane są następnie przy modelowaniu filmu olejowego, natomiast przemieszczenia pierścieni i natężenie przedmuchów służą do jakościowej oceny działania uszczelnienia TPC. Wpływ przyjętej intensywności wymiany ciepła na wymienione wielkości, istotne $\mathrm{z}$ punktu widzenia celu obliczeń, nie jest już tak duży. Jednak różnice między wyznaczonymi wartościami tych wielkości, zwłaszcza przy przyjętym przepływie izotermicznym, a uwzględniającym umiarkowaną intensywność wymiany 
temperatures is not the key objective in such calculations. More important are other quantities: pressures are used for modeling of the oil film, displacements of rings and blow by rates are used for the qualitative evaluation of the ring pack. The influence of the assumed intensity of the heat transfer on the above quantities (which are significant) considering the aim of the calculations, was moderate. However, there were significant differences between the results of simulations run at the assumed moderate heat transfer and isothermal flow. For example, a blow by at an isothermal flow was up to $40 \%$ higher than in the case of the flow where moderate heat transfer intensity was assumed. In certain cases differences were not only of quantitative but also qualitative nature, e.g. different number of ring movements in the groove.

Without establishing how different the real flow is from isothermal it can be stated that calculating parameters of the gas from the energy balance equation used in the presented model is more general in comparison to the models in which the isothermal flow was assumed. The presented approach allows modeling of a gas flow with different heat transfer intensity including adiabatic and isothermal flows (special cases). ciepła, są znaczące. Na przykład natężenia przedmuchów spalin wyznaczone przy przepływie izotermicznym były do $40 \%$ większe niż przy przepływie, w którym założono umiarkowaną intensywność wymiany ciepła. W pewnych przypadkach różnice mogą mieć nie tylko charakter ilościowy, ale również jakościowy, np. różna liczba przemieszczeń pierścienia w rowku.

Nie rozstrzygając, czy rzeczywisty przepływ bliższy jest izotermicznemu, czy adiabatycznemu z całą pewnością uwzględnianie wymiany ciepła i wyznaczanie parametrów czynnika $\mathrm{z}$ równania bilansu energii jest bliższe rzeczywistości, niż w powszechnie stosowanych modelach, w których zakłada się, że przepływ jest izotermiczny. Ponadto zaproponowany model jest bardziej uniwersalny, gdyż pozwala modelować działanie uszczelnienia TPC przy różnej intensywności wymiany ciepła pomiędzy gazem a otaczającymi go ściankami, w tym, jako przypadkach szczególnych, przy przepływie adiabatycznym lub izotermicznym.

Paper reviewed

\section{Nomenclature/Skróty i oznaczenia}

$\alpha$ heat transfer coefficient/wspótczynnik wymiany ciepła

$\mathrm{c}_{\mathrm{v}} \quad$ specific heat at constant volume/ciepło właściwe przy stałej objętości

i specific enthalpy of the gas/entalpia wtaściwa gazu

$\mathrm{m}$ mass of the gas in a stage/masa gazu w stopniu uszczelnienia

$\mathrm{p}$ pressure of the gas in a stage/ciśnienie gazu w stopniu uszczelnienia

Q heat transferred to the surrounding walls/ciepto wymieniane z otaczajacymi ściankami

$\mathrm{R}$ the gas constant/stała gazowa

$\mathrm{S}$ surface area of the heat transfer/pole powierzchni wymiany ciepta

$\mathrm{T}$ temperature of the gas in a stage/temperatura gazu $w$ stopniu uszczelnienia
V volume of the stage/objętość stopnia

$\mathrm{u}$ specific internal energy of the gas in the stage/energia wtaściwa wewnętrzna gazu w stopniu

$\mathrm{U}$ internal energy of the gas in the stage/energia wewnętrzna gazu w stopniu

\section{Indexes/indeksy:}

c relating to cylinder/dotyczacy cylindra

$\mathrm{p}$ relating to piston/dotyczacy tłoka

$\mathrm{r}$ relating to ring/dotyczacy pierścienia

wall relating to surrounding wall/dotyczacy otaczajacej ścianki

in incoming to the stage/naptywajacy do stopnia

out outgoing from the stage/wyptywajacy ze stopnia

\section{Bibliography/Literatura}

[1] Keribar R., Dursunkaya Z., Flemming M. F.: An Integrated Model of Ring Pack Performance. Journal of Engineering for Gas Turbines and Power, Vol. 113, pp. 382-389, 1991.

[2] Koszałka G.: Modelling the blowby in internal combustion engine, Part 1: A mathematical model. The Archive of Mechanical Engineering, Vol. LI, No. 2, pp. 245-257, 2004.

[3] Koszałka G.: Modelling the blowby in internal combustion engine, Part 2: Primary Calculations and Verification of the

Grzegorz Koszalka, DEng. - Assistant Professor in the Faculty of Mechanical Engineering at Lublin University of Technology.

Dr inż. Grzegorz Koszałka - adiunkt na Wydziale Mechanicznym Politechniki Lubelskiej. e-mail: g.koszalka@pollub.pl
Model. The Archive of Mechanical Engineering, Vol. LI, No. 4, pp. 595-607, 2004

[4] Namazian M., Heywood J. B.: Flow in the Piston-Cylinder-Ring Crevices of a Spark-Ignition Engine: Effect on Hydrocarbon Emissions, Efficiency and Power. SAE Paper 820088, 1982.

[5] Sygniewicz J.: Modelowanie współpracy tłoka z pierścieniami tłokowymi i tuleją cylindryczną. Łódź, Wydawnictwo Politechniki Łódzkiej (Zeszyty Naukowe Nr 615, Rozprawy Naukowe z. 149), 1991.

[6] Tian T., Noordzij L. B., Wong V. W., Heywood J. B.: Modeling Piston-Ring Dynamics, Blowby and Ring-Twist Effects. Journal of Engineering for Gas Turbines and Power, Vol. 120, No 4, pp. 843-854, 1998.

[7] Ting L. L., Mayer J. E. Jr.: Piston Ring Lubrication and Cylinder Bore Wear Analysis. Part II - Theory Verification. Journal of Lubrication Technology, Vol. 96, pp. 258-266, 1974.

[8] Wolff A.: Numerical simulation of piston ring pack operation with regard to blowby, lubrication and ring twist effect. Silniki spalinowe - Combustion engines, 2007-SC1, pp. 145-159. 